\title{
Comparative Analysis of Air Emission from Cement Plant Using TDF as Partial Substitute for Coal
}

\author{
Fateha Arshed ${ }^{1}$, Amtul Bari Tabinda ${ }^{1}$, Syed Ali Raza ${ }^{2}$, Aleem Butt ${ }^{2}$, \\ Abdullah Yasar ${ }^{1}$ \\ ${ }^{I}$ Sustainable Development Study Centre, Government College University Lahore, Pakistan \\ ${ }^{2}$ Solution Environmental Analytical Laboratory, Kot Lakhpat, Lahore Pakistan \\ cross $^{\text {ref }}$ http://dx.doi.org/10.5755/j01.erem.68.2.6471
}

(Received in April, 2014; accepted in June, 2014)

\begin{abstract}
Tyre derived fuel (TDF) has a potential advantage for its use as a co-fuel with coal in rotary kilns of cement plants. In this study we analyzed the emissions of selected criteria pollutants; $\mathrm{CO}_{2}, \mathrm{CO}, \mathrm{NO}_{\mathrm{x}}, \mathrm{SO}_{x}$ and PM to suggest suitable proportion of TDF to replace coal when different proportions of TDF and coal were used as cement kiln feed. Emissions of $\mathrm{CO}_{2}, \mathrm{CO}, \mathrm{NO}, \mathrm{NO}_{2}, \mathrm{SO}_{2}$ and total PM from stack and concentrations of $\mathrm{CO}, \mathrm{NO}_{\mathrm{x}}, \mathrm{SO}_{\mathrm{x}}$ and $\mathrm{PM}_{10}$ in ambient air were assessed using USEPA recommended methods. Substitution such as $85 \%$ coal and $15 \%$ TDF, $80 \%$ coal and 20\% TDF, 75\% coal and 25\% TDF and $70 \%$ coal and $30 \%$ TDF were applied in this study. Results of the current study revealed a rise in CO and TPM stack emissions with an increase in proportions of TDF and crossed standards at $80 \%$ coal and $20 \%$ TDF. Decline in $\mathrm{NO}_{\mathrm{x}}$ emissions up-till $15 \%$ proportion of TDF was observed and remained lower than the emission of $\mathrm{NO}_{\mathrm{x}}$ at $100 \%$ coal use in spite of an increase in its concentration at each increased proportion of TDF above 15\% TDF use. No significant difference ( $p>0.05)$ in ambient air pollutant concentration with and without TDF use was observed. The study suggested 15\% TDF substitution as a preferable proportion for the selected cement plant.
\end{abstract}

Keywords: air emission, cement industry, tyre derived fuel, coal, fuel substitution

\section{Introduction}

It is of significance to ponder upon environmental implications of cement production because of its abundance in world market. On average approximately 1 ton of concrete is produced each year for every human being in the world (Lippiatt and Ahmad, 2005). Asia is the biggest producer among the world cement producing regions, as it contributed $67.60 \%$ of the total cement produced worldwide (Ali et al., 2011). Cement manufacturing process is a multistage process. Each step of cement production is associated with certain emissions (Chen et al., 2010). To meet energy demand of this industry, petroleum, oil, natural gas and coal are mostly used (Eckert et al., 1997). Among these, coal is at priority to generate energy for cement manufacturing (CEC 2003), more prominently in developing countries. Burning of fuel especially coal releases considerable amount of carbon dioxide in the atmosphere (Photovoltaics Bulletin, 2002; O'Keefe et al., 2010; Ali et al., 2011).
The processes involving combustion of fuel are mostly responsible for emissions of $\mathrm{NO}_{\mathrm{x}}$ and $\mathrm{SO}_{\mathrm{x}}, \mathrm{CO}$ and $\mathrm{O}_{3}$ along with $\mathrm{PM}$ (particulate matter), while crushing, grinding and mixing are major contributors to particulate matter (Sabah and Whab, 2006). High temperature in cement plant provides very favorable conditions for NOx formation (USEPA, 1994). Burning of high sulfur coal results in higher $\mathrm{SO}_{2}$ emission than burning of lower sulfur coal (0.4-1\%) (Krylove, 2002). Pakistani coal has high sulfur content (Sharif et al., 2005; Ali et al., 2008). Sulfur content in Pakistani coal ranges from as much low as $0.20 \%$ to very high proportion i.e. $15 \%$ (Private Power and Infrastructure Board, 2004). There are 29 cement producing companies in Pakistan. Total production of cement increased from 8 million tons in 1996 to 22.50 million tons in 2007 (State Bank of Pakistan, 2007). Increase in production cannot be achieved independent of the energy requirements. It 
has been estimated that cement industry consumes about 12-15 percent of the total energy used in industry (Madlool et al., 2011). It reveals that the cement manufacturing is an energy intensive process (Deborah et al., 2009). Coal is a cheaper energy resource therefore is widely used to derive energy in energy intensive processes (Smith, 2003; Gineys et al., 2011). To meet the elevating energy demand in industrial sector there is a need to adopt rational measures to avoid tradeoff between the environment and economic prosperity. Since last decade efforts have been made to find out a better option for fossil fuel substitution with waste materials in cement manufacturing (Gineys et al., 2011). Substitution of cement plant fuel with tyres and sewage sludge, refused derived fuel, waste carpets and resultant change in emissions has been studied worldwide (Carrasco et al., 2002; Lemieux, 2003; Abad et al., 2004; Pipilikaki et al., 2005; Conesa et al., 2008). Using waste tyres as fuel is a more economical option. It not only reduces the demand for coal acquisition, but it is also less expensive (Pipilikaki et al., 2005), and a good practice for reuse of waste tyres instead of incinerating or dumping in landfill (Conesa et al., 2008). Fuel type is one of the most significant factor influencing air emissions (Giannopoulos et al., 2007; Boughton, 2007; Zabaniotou and Theofilou, 2008; Conesa et al., 2008). This study aims to find the suitable proportion of tyre derived fuel (TDF), which could be used as co-fuel in combination of coal in cement kiln. 1 ton of TDF can replace 1.2 tons of coal as analyzed for kiln of the selected cement plant. It has higher calorific value i.e. $31400 \mathrm{~kJ} / \mathrm{kg}$ (Pipilikaki et al., 2005). If coal were fully replaced by TDF, the average requirement of TDF would be as 259 (250267tons/day) tons per day. The present study compares the air emissions by use of coal as the only heat source and at different proportions of coal and TDF in kiln. Comparisons were made for both stack emissions and ambient air. Stack emissions analysis included $\mathrm{CO}_{2}, \mathrm{CO}, \mathrm{NO}, \mathrm{NO}_{2}, \mathrm{SO}_{2}$ and total PM. While ambient air analysis included only $\mathrm{CO}, \mathrm{NO}_{\mathrm{x}}$, $\mathrm{SO}_{\mathrm{x}}$ and $\mathrm{PM}_{10}$.

\section{Methods}

\subsection{Study area}

Study was conducted in Pioneers Cement Plant situated in Jauharabad $\left(32^{\circ} \mathrm{N}, 72^{\circ} \mathrm{E}\right)$ district Khushab in central Punjab Pakistan. Climate of Khushab is governed by very diverse components of land forms; plain area, hills, desert and agriculture area. The study was conducted in the month of March 2012. Data about wind direction, wind speed, and daily average temperature and humidity of Jauharabad $\left(32^{\circ} \mathrm{N}^{\prime} 72^{\circ} \mathrm{E}\right)$ were obtained from the Pakistan Meteorology Department, as these are necessary to select sampling points and understanding the variations in pollutants concentrations (Kordova et al., 2011).

\subsection{Cement production plant}

The plant comprises two production lines (line1 and line 2), having daily production of clinker as $2000 t /$ day-6000t/day. Both lines of production are well equipped with electrostatic precipitators and cyclones for dust collection. Each production setup has two stacks i.e., one stack for exhaust of combustion kiln and second is the stack for coal mill. The plant consists of raw material crusher, coal crusher, gypsum crusher, stackers, grinders, raw mixers, kiln, three cement mills and three silos. The height of the selected combustion kiln stack of line one is $200 \mathrm{ft}$. The temperature in the cement kiln remains above $1550 \mathrm{C}^{0}$ at the time of clinker formation. The plant uses both Pakistani and Indonesian coal as its heat source. An average daily energy requirement is up to $5000 \mathrm{MJ} /$ ton. The amount of coal required in combustion kiln of production line 1 is 300 to 320 tons coal/day. American imported shredded TDF was used as a substitute in this study. TDF and coal ratio was adjusted as not to disturb the energy demand and temperature in the kiln during combustion. TDF was used in the proportion, which could not only replace more amount of coal with less amount of TDF, but also maintained the temperature in the kiln before and after substitutions. Five substitutions were given to reach the suitable coal and TDF ratio. Table 1 mentioned the percentage ratio adjustment scheme of two fuels in each of five proportional substitutions. Gaseous emissions and PM concentrations in the exhaust from stack at each substitution were determined.

Table 1. Proportions of coal and TDF in each substitution and combustion conditions

\begin{tabular}{||l|l|l|l|l||}
\hline $\begin{array}{l}\text { Substitution } \\
\text { No }\end{array}$ & $\begin{array}{l}\text { Proportion of coal } \\
\text { and TDF, } \\
\text { \% }\end{array}$ & $\begin{array}{l}\text { Amount of coal and TDF, } \\
\mathbf{t}\end{array}$ & $\begin{array}{l}\text { Kiln } \\
\text { temperature, } \\
\mathbf{C}^{\mathbf{0}}\end{array}$ & $\begin{array}{l}\text { Oxygen in combustion } \\
\text { exhaust, } \\
\text { \% }\end{array}$ \\
\hline S0 & $100: 0$ & $310: 00$ & 1600 & 10.39 \\
\hline S1 & $85: 15$ & $264: 39$ & 1560 & 11.24 \\
\hline S2 & $80: 20$ & $248: 52$ & 1580 & 9.97 \\
\hline S3 & $75: 25$ & $233: 65$ & 1575 & 9.75 \\
\hline S4 & $217: 77$ & 1550 & 10.60 \\
\hline
\end{tabular}




\subsection{Ambient air quality monitoring}

Selection of sampling points was based on identification of source activity and place for its accomplishment and wind direction. Fuel burning during clinker formation is the main source of $\mathrm{NO}_{\mathrm{x}}$, $\mathrm{SO}_{\mathrm{x}}, \mathrm{CO}_{2}, \mathrm{PM}$ and $\mathrm{CO}$ from a cement plant (Walters et al., 1999; Baris et al., 2000; Deja et al., 2010; Lei et al., 2011). Steps involving physical processing of raw material such as crushing, pilling, and grinding are of significance as being the source of particulate matter (Sabah and Wahab, 2006; Branquinho et al., 2008). Ambient air gaseous parameters and $\mathrm{PM}_{10}$ in nearby fields were analyzed at $100 \%$ coal and substitution 4 . The sample of ambient air gaseous parameters and $\mathrm{PM}_{10}$ in nearby fields was collected at a point of stack deposition. Plume of selected stack was falling on ground approximately at the distance of $2 \mathrm{~km}$ from the source in the direction of wind. The sampling point was observable due to falling of hazy colored plume contributed by PM, and other gaseous emissions. In both cases that were before and after fuel substitution this point was selected for measurement of ambient $\mathrm{NO}_{\mathrm{x}}, \mathrm{SO}_{\mathrm{x}}, \mathrm{CO}$, and $\mathrm{PM}_{10}$ levels contributed by cement kiln. For ambient air, $\mathrm{CO}$ was measured using HORIBA APMA 360 analyzer (equivalent method RFCA-0895-106, USEPA, 2011), NOx with help of HORIBA APNA 360 NOx analyzer (RFNA-0196111, USEPA 2011), $\mathrm{SO}_{2}$ using HORIBA APSA 360 $\mathrm{SO}_{2}$ analyzer (EQSA0197-114, USEPA, 2011), particulate matter was collected using integrated air sampler (IO 2.3, USEPA, 2011) and the amount of $\mathrm{PM}_{10}$ was calculated by a gravimetric method (USEPA, 1999).

\subsection{Measurement of stack emissions}

For stack emissions parameters; $\mathrm{CO}_{2}, \mathrm{CO}, \mathrm{NOx}$, $\mathrm{SO}_{2}$, and total PM were measured using Testo $350 \mathrm{XI}$ Germany as recommended (Baghdar et al. 2010, Udeozor and Nzeako 2012). The temperature in kiln was similar while measuring contaminants on $100 \%$ coal use and after substitutions with TDF. The amount of oxygen was also measured in combustion exhaust stack using Testo 350XI.

\section{Results and discussion}

The meteorological data re the day of monitoring were represented in Table 2. General meteorological parameters exhibit a key role in site selection. Analysis of gaseous emissions and total PM at 100\% coal use with respect to variation in meteorological parameters revealed that with $11 \%$ rise in the average 24 hour temperature and $1.3 \%$ decrease in relative humidity, $\mathrm{CO}_{2}$ emission from stack elevated up to $3 \%$, $\mathrm{CO}$ up to $20 \%, \mathrm{NO}_{\mathrm{x}}$ up to $5 \%$, no change in $\mathrm{SO}_{2}$ concentration, and $8 \%$ decrease in TPM was assessed.

Table 2. Meteorological conditions at each day of experiment

\begin{tabular}{||l|l|l|l|l||}
\hline Substitution & $\begin{array}{l}\text { Average temperature, } \\
\mathbf{C}^{\mathbf{0}}\end{array}$ & $\begin{array}{l}\text { Wind speed, } \\
\mathbf{m} / \mathbf{s}\end{array}$ & $\begin{array}{l}\text { Relative humidity, } \\
\mathbf{\%}\end{array}$ & $\begin{array}{l}\text { Precipitation, } \\
\mathbf{m m}\end{array}$ \\
\hline S0 & 19.00 & 1.028 & 77.00 & 0.00 \\
\hline S1 & 17.50 & 0.00 & 81.00 & 0.00 \\
\hline S2 & 19.50 & 1.028 & 77.00 & 0.00 \\
\hline S3 & 18.50 & 1.028 & 82.00 & 0.00 \\
\hline S4 & 19.75 & 1.028 & 83.00 & 0.00 \\
\hline
\end{tabular}

The highest concentration in stack exhaust was found for CO a well known hazardous gas (494.39 $\mathrm{mg} / \mathrm{Nm}^{3}$ ). Stack emissions analysis did not show any $\mathrm{SO}_{2}$ contamination (Table 3). All the concentrations obtained after substitutions were compared to the concentrations at $100 \%$ coal use. At all the substitutions average temperature and humidity did not vary more than $11 \%$ and $7 \%$, respectively, and precipitation was 0 at all days of experiment. The temperature in kiln did not vary significantly before and after different substitutions. It varied between $1550 C^{\circ}-1600 C^{\circ}$. So the mentioned variations in emissions may be solely regarded to fuel substitution. At $\mathrm{S} 1$ decrease of $11 \%(\mathrm{p}>0.05)$ in $\mathrm{CO}_{2}$ and $51 \%$ in NOx was assessed, While elevations in release of $\mathrm{CO}$ and TPM $(5.4 \%$ and $1.13 \%$, respectively) were negligible $(\mathrm{P}>0.05)$ as compared to $100 \%$ coal use. No change in $\mathrm{SO}_{2}$ was observed.

Table 3. Concentration of gaseous pollutants and PM from the stack of cement plant at different proportions of coal and $T D F$

\begin{tabular}{||l|l|l|l|l|l||}
\hline \hline $\begin{array}{l}\text { Parameters } \\
\text { (gaseous } \\
\text { pollutants and } \\
\text { PM) }\end{array}$ & $\mathrm{S} 0$ & $\mathrm{24}$ hour average concentration of pollutants for 100\% coal and different substitution of TDF \\
\cline { 2 - 6 } & $9.45 \pm 0.13$ & $8.55 \pm 1.00$ & $\mathrm{~S} 2$ & $\mathrm{~S} 3$ & $\mathrm{~S} 4$ \\
\hline $\mathrm{CO}_{2}, \%$ & $614.99 \pm 28.00$ & $650.39 \pm 80.00$ & $951.20 \pm 272.00$ & $9.39 \pm 0.02$ & $9.25 \pm 0.20$ \\
\hline $\mathrm{CO}, \mathrm{mg} / \mathrm{Nm}^{3}$ & $309.39 \pm 4.0$ & $153.10 \pm 17.00$ & $216.29 \pm 23.00$ & $206.29 \pm 24.00$ & $220.29 \pm 41.10$ \\
\hline $\mathrm{NO}_{\mathrm{x}}, \mathrm{mg} / \mathrm{Nm}^{3}$ & $0.00 \pm 0.00$ & $0.00 \pm 0.00$ & $0.00 \pm 0.00$ & $0.90 \pm 0.51$ & $1.49 \pm 1.00$ \\
\hline $\mathrm{SO}, \mathrm{mg} / \mathrm{Nm}^{3}$ & $408.59 \pm 33.20$ & $413.29 \pm 0.00$ & $444.49 \pm 26.00$ & $541.00 \pm 77.00$ & $2,831.90 \pm 247.40$ \\
\hline $\begin{array}{l}\text { Total PM}, \\
\mathrm{mg} / \mathrm{Nm}^{3}\end{array}$ &
\end{tabular}


Concentrations of all selected parameters were within the limits defined by Pak. EPA (2011) except total PM, which crossed the standard $\left(300 \mathrm{mg} / \mathrm{Nm}^{3}\right)$ not only at S1 but at $100 \%$ coal as well. At S2 there was no considerable $(\mathrm{P}>0.05)$ change in $\mathrm{CO}_{2}$ concentration $(2 \%)$, but remarkable decline $(\mathrm{p}<0.05)$ in $\mathrm{NOx}$ i.e. $30 \%$ was observed. Results revealed that $\mathrm{CO}, \mathrm{SO}_{2}$ and TPM concentration increased in stack emissions with increase in proportion of TDF used. Increase in emissions of CO $(35.3 \%)$ and TPM $(8.1 \%)$ was observed exceeding the concentrations measured at $\mathrm{S} 1$. CO concentration as $951.20 \mathrm{mg} / \mathrm{Nm}^{3}$ crossed the NEQS i.e. $800 \mathrm{mg} / \mathrm{Nm}^{3}$. The trend was disturbed at $\mathrm{S} 3$. The parameters which were on decrease at $\mathrm{S} 1$ $\left(\mathrm{CO}_{2}\right.$ and $\left.\mathrm{NO}_{\mathrm{x}}\right)$ showed further decline in concentrations at S3. Slight decrease in $\mathrm{CO}_{2}$ i.e. $2.1 \%$ and NOx (33.3\%) was assessed. There was incline in $\mathrm{CO}(35 \%), \mathrm{SO}_{2}(100 \%)$ and TPM (25\%). This increase in $\mathrm{CO}$ led to violation of the national air quality standard for $\mathrm{CO}$. At S4 an increase in all the considered pollutants has been observed except $\mathrm{CO}_{2}$. $\mathrm{CO}_{2}$ decreased up to $3.6 \%$ and was also lower than the concentration at S3. Although the kiln temperature did not vary significantly, but increase in oxygen and decrease in $\mathrm{CO}_{2}$ at $\mathrm{S} 1$ and $\mathrm{S} 4$ might be due to decrease in the temperature. $29 \%$ decrease in NOx was assessed as compared to $100 \%$ coal use, while the concentrations higher than the concentrations at S3. $\mathrm{CO}$ increased $50 \%$. It crossed the concentration emitted at $\mathrm{S} 3$ and national standard as well. $\mathrm{SO}_{2}$ reached at $1.49 \mathrm{mg} / \mathrm{Nm}^{3}$ from 0 which was the highest among all substitutions, and is within the standard limit $\left(1700 \mathrm{mg} / \mathrm{Nm}^{3}\right)$. TPM was considerably elevated, i.e. $86 \%$ and also crossed the values obtained at S3. It reached up to $2831.90 \mathrm{mg} / \mathrm{Nm}^{3}$ and crossed the standard $\left(300 \mathrm{mg} / \mathrm{Nm}^{3}\right)$. Use of waste material and used tyres was adapted as a tool to reduce $\mathrm{CO}_{2}$ and NOx emissions reduction from the cement kiln to comply with regulatory requirements. Studies reported the achievement of lower $\mathrm{CO}_{2}, \mathrm{NO}_{\mathrm{x}}$ emissions as a result of fuel substitution (Conesa et al. 2008; Deja et al., 2010). $\mathrm{CO}_{2}$ showed a continuous declining trend with increase in the amount of TDF and decrease in the amount of coal. Literature supports the view that there is no significant change in stack emissions during the use of TDF in comparison with coal (Pipilikaki et al., 2005; Middleton et al., 2008). The pilot scale study conducted by Carrasco et al. supports the results of this study. It states $37 \%$ increase in $\mathrm{CO}$ emission, $24 \%$ increase in $\mathrm{SO}_{2}$ and $11 \%$ decrease in $\mathrm{NO}_{\mathrm{x}}$ emissions, when TDF is fed to kiln along with coal (Carrasco et al., 2002). Carbon and nitrogen content of waste material, combustion properties, feeding place, and retention time are often controlling factors for the $\mathrm{CO}$ and $\mathrm{NO}_{\mathrm{x}}$ emission (Lemieux et al., 2004). Coal is responsible for greater $\mathrm{NO}_{\mathrm{x}}$ emissions as compared to TDF. In this study substitution of coal with TDF leads to lesser $\mathrm{NO}_{\mathrm{x}}$ emissions (including $\mathrm{NO}$ and $\mathrm{NO}_{2}$ ). The trend in $\mathrm{NO}_{\mathrm{x}}$ emission in this analysis has not been linear, as $\mathrm{NO}_{\mathrm{x}}$ emissions from cement manufacturing are always excessively variable (Walters et al., 1999). $\mathrm{SO}_{2}$ elevated non-significantly $(\mathrm{p}>0.05)$ only at higher proportion of TDF i.e. $25 \%$ and $30 \%$. In clinker formation about $75-80 \%$ of $\mathrm{SO}_{2}$ is absorbed by lime stone and some of proportion remains at the bottom of the combustion kiln. So $\mathrm{SO}_{2}$ pollution from kiln remains negligible (Yang et al., 2003). A large increase in PM in S3 and S4 is unusual in this experiment; increase in the amount of TDF can be a good justification for this. Raw material input and operational conditions could also be reasons for increase in TPM emissions from stack.

The level of pollutants in nearby fields of a point source is often the point of concern for regulatory authorities and health scientists (Hajra et al. 2011). Ambient air analysis at a considerable distance from the point source (Table 4) that is stack of the cement plant implores that there was no significant variation $(p>0.05)$ in the concentrations of these pollutants as compared to the values obtained at $100 \%$ coal use. Comparison between the ambient air concentrations in nearby field at the point of stack deposition for $100 \%$ coal and S4 indicated no correlation between stack emissions and ambient air concentration. Ambient air concentrations at the point of stack deposition did not exceed the USEPA (2011), WHO (1998), PAK EPA (2012), and WB (2012) ambient air quality standards.

Table 4. Ambient air concentration outside the vicinity of cement plant at 100\% coal use and maximum proportion of TDF

\begin{tabular}{||l|l|l|l||}
\hline Sr. No & Parameters & $\begin{array}{l}\text { 24 hour average concentration } \\
\text { at S0 }\end{array}$ & $\begin{array}{l}\mathbf{2 4} \text { hour average concentration } \\
\text { at S4 }\end{array}$ \\
\hline 1 & $\mathrm{CO}, \mathrm{mg} / \mathrm{m}^{3}$ & $0.36 \pm 0.007$ & $0.65 \pm 0.006$ \\
\hline 2 & $\mathrm{NO}_{2}, \mu \mathrm{g} / \mathrm{m}^{3}$ & $20.30 \pm 0.900$ & $19.50 \pm 0.006$ \\
\hline 3 & $\mathrm{SO}_{2}, \mu \mathrm{g} / \mathrm{m}^{3}$ & $14.00 \pm 0.041$ & $12.30 \pm 0.006$ \\
\hline 4 & $\mathrm{PM}_{10}, \mu \mathrm{g} / \mathrm{m}^{3}$ & $140 \pm 0.041$ & $138.00 \pm 0.041$ \\
\hline
\end{tabular}

Micrometeorological parameters play a critical role in dilution, dispersion, and sampling (Goyal et al., 1996). The sampling point in nearby field was the same at $100 \%$ coal use and at the maximum level of substitution i.e. $\mathrm{S} 4$, because of the fact that wind was calm and wind speed $(1.028 \mathrm{~m} / \mathrm{s})$ was the same on the day of substitution, which led to the deposition of exhaust at the same place as it was on the day of $100 \%$ coal use. Although in the present study, temperature and precipitation did not play a governing role in variations in the ambient air concentration in nearby field, because there was no significant change in the average temperatures of the two respective days and precipitation was also 0 , therefore the change in relative humidity could be the contributing factor. Decrease in $\mathrm{NO}_{2}, \mathrm{SO}_{2}$ and $\mathrm{PM}_{10}$ at substitution 4 can be attributed to increase of $6 \%$ in relative humidity. There was no huge difference in ambient air 
pollutants concentration at $100 \%$ coal use and substitution 4 . No change in wind speed and direction on the two different days of measurement provides a good reason for it, as both are primary factors in dilution of pollution (Berkowicz et al. 1996). The study was limited due to unavailability of ambient air quality data of pollutants before deposition due to continuity of the manufacturing process. The obtained concentration of pollutants cannot be wholly regarded to stack emissions, as natural sources of the area always contribute to the ambient pollution level. PM level also depends upon land form of the area (Middleton et al., 2008; Ward and Lange, 2010), and the distance from stack or stack height (Godoy et al., 2009). The cement plant under consideration contains and is surrounded by the unpaved barren landscape leading to the greater air PM level. Ambient air analysis at minimum and medium substitution of coal for TDF other than these proportions is also lacking, which could provide a clearer picture for selection of most suitable coal TDF proportion. A considerable decrease in NOx emissions and decline in $\mathrm{CO}_{2}$ with increase in each proportion of TDF renders it preferable fuel. Results of the study suggest only proportional substitution of coal with TDF due to a considerable rise in $\mathrm{CO}$ and $\mathrm{PM}$ concentration from stack emissions with an increase in the amount of TDF substituted as fuel.

\section{Conclusions}

This industrial scale fuel substitution experiment demonstrated the potential for waste tyres to be used as a fuel in cement kiln taking the environment as priority. Comparison of results obtained from 100\% coal use and $15 \%$ TDF use indicated only negligible increase in CO and TPM from stack emissions. While all other pollutants decreased considerably from their concentration level at $100 \%$ coal use. At $20 \%$ and $25 \%$ TDF substitution there was a decline in $\mathrm{CO}_{2}$ and NOx, but a significant increase in $\mathrm{CO}$ and TPM. Similarly at the maximum $30 \%$ substitution, although decline in NOx emissions was considerable, $\mathrm{CO}$ and TPM immensely increased. The ambient air concentrations of parameters CO, NOx, Sox, and $\mathrm{PM}_{10}$ did not show significant difference as compared to the ambient air levels of gaseous emissions and $\mathrm{PM}_{10}$ at $100 \%$ coal use. The study suggests $85 \%$ coal and $15 \% \mathrm{TDF}$ as the most suitable proportion of the TDF among all proportions used in current studies for the selected cement plant, which could not be generalized for other cement plants of different properties.

\section{Acknowledgements}

We are grateful to Solution Environmental Analytical Laboratory for provision of technical assistance. We also express our gratitude to the Pakistan Meteorological Department for providing meteorological data.

\section{References}

Abad E., Martinez K., Caixach J., Rivera J. (2004), Polychlorinated dibenzo PCDD/PCDF/polychlorinated dibenzofuran releases into the atmosphere from the use of secondary fuels in cement kilns during clinker formation. Environmental Science and Technology, 18(38), p.47344738; http://dx.doi.org/10.1021/es049641a;

Ali A., Ahmad N., Shah R., Bhatti M. N., Saleem M. (2008), Coal desulfurization by Solvent Leaching Methods. Journal of Faculty of Engineering \& Technology, (15), p.47-56;

Ali M.B., Saidur R., Hossain M.S. (2011), A review on emission analysis in cement industries. Renewable and Sustainable Energy Reviews, 5(15), p. 2252-2261; http://dx.doi.org/10.1016/j.rser.2011.02.014;

Baghdar S., Hosseini, Bashirnezhad K., Moghiman A.R., Khazraii Y., Nikoofal N. (2010), Experimental comparison of combustion characteristic and pollutant emission of gas oil and biodiesel. International Journal of Mechanical and Materials Engineering, 1(1), p. 10-13;

Baris R., Canpolat, Atimtay A.T., Munlafalioglu I., Kalafatoglu E. And Ekinci E. (2000), Emission Factors of Cement Industry in Turkey. Water, Air, \& Soil Pollution, 14(138), p. 235-252. DOI: 10.1023/A: 101550213118002;

Berkowicz R., Palgrem F., Hertel O. And Vignati E. (1996), Using measurements of air pollution in streets for evaluation of urbane air quality meteorological analysis and model calculation. Science of Total Environment, 190(189), p. 259-265; http://dx.doi.org/10.1016/0048-9697(96)052175

Boughton B. (2007), Evaluation of shredder residue as cement manufacturing feedstock. Resource Conservation and Recycling, 3(51), p. 621-642; http://dx.doi.org/10.1016/j.resconrec.2006.11.006;

Branquinho C., Oliveira G. G., Augusto S. P., Pinho, Máguas C. And Correia O. (2008), Biomonitoring spatial and temporal impact of atmospheric dust from a cement industry. Environmental pollution, 2(151), p. 292-299; http://dx.doi.org/10.1016/j.envpol.2007.06.014;

Carrasco F., Bredin N. And Heitz M. (2002), Gaseous contaminant emissions as affected by burning scrap tyres in cement manufacturing. Journal of Environmental Quality, 5(31), p. 1484-1490; http://dx.doi.org/10.2134/jeq2002.1484;

Chen C., Habert G. A., Bouzidi Y. A., And Jullien (2010), Environmental impact of cement production: detail of the different processes and cement plant variability evaluation. Journal of Cleaner Production, 5(18), p. 478485; http://dx.doi.org/10.1016/j.jclepro.2009.12.014;

Conesa J.A., Galvez A.G., Mateos F., Mart'InGull'On I., And Font R. (2008), Organic and inorganic pollutants from cement kiln stack feeding alternative fuels. Journal of hazardous material, 2-3(158), p. 585-592; http://dx.doi.org/10.1016/j.jhazmat.2008.01.116;

Deborah N., Huntzinger Thomas D. And Eatmon. A (2009), Life-cycle assessment of Portland cementmanufacturing: comparing the traditional process 
with alternative technologies. Journal of Cleaner Production, 2009, 7(17), p.668-675;

Deja J., Bochenczyk A. U., Mokrzycki E. (2010), $\mathrm{CO} 2$ emissions from Polish cement industry. International Journal of Greenhouse Gas Control, 4(4), p. 583-588; http://dx.doi.org/10.1016/j.ijggc.2010.02.002;

Eckert J., James O., Guo, Qizhong (1997), Heavy metals in cement and cement kiln dust from kilns co-fired with hazardous waste-derived fuel: application of EPA leaching and acid-digestion procedures. Journal of Hazardous Material, 1997, 1(59), p. 55-93;

EPA. 1999. Compendium methods for determination of inorganic compounds in ambient air. United Sates Environmental Protection Agency, EPA/625/R-96/010a;

EPA. 2011. List of designated, reference and equivalent methods national exposure research laboratories. Humane exposure and atmospheric science division, United States Environmental Protection Agency (www.epa.gov/ttn/amtic/criteria.html);

USEPA. 2011. National Ambient Air Quality Standards. United States Environmental Protection Agency;

Giannopoulos D., Kolaitis D.I., Togkalidou A., Skevis G., Founti M.A. (2007), Quantification of emissions from the co-incineration of cutting oil emulsions in cement plants - Part I: NOx, CO and VOC. Fuel Guildford, 2007, 7-8(86), p. 1144-1152;

Gineys N., Aouad G., Sorrentino F., Damidot D. (2011), Incorporation of trace elements in Portland cement clinker: Thresholds limits for $\mathrm{Cu}, \mathrm{Ni}, \mathrm{Sn}$ or $\mathrm{Zn}$. Cement and Concrete Research, 11(41), p.1177-1184;

Godoy S.M., Mores P.L., Santa S.M., Cruz, Scenna N.J. (2009), Assessment of impact distances for particulate matter dispersion. A stochastic approach. Reliability Engineering \& System Safety, 10(94), p. 1658-1665;

Goyal P., Singh M.P., Gulati M.P. (1996), Air quality assessment of the environment over a cement industrial complex. Atmospheric Environment, 7(30), p. 1159-1166;

Hajra B., Stathopoulos T., Bahloul A. (2011), The effect of upstream buildings on near-field pollutant dispersion in the built environment. Atmospheric Environment, 28(45), p. 4930-4940;

CEC. 2003. Energy use in the cement plant industry in North America: emissions, waste generation and pollution control, 1990-2001. $2^{\text {nd }}$ North American Symposium on Assessing the Environmental Effects of Trade, Commission for Environmental Cooperation;

Krylove D.A. (2002), Effect Of Heating and Power Plants on the Environment. Atomic Energy, 6(92), p. 523528. DOI: 10.1023/A: 1020278502060;

Lei Y., Zhang Nielsen C. and He K. (2011), An inventory of primary air pollutants and $\mathrm{CO} 2$ emissions from cement production in China, 1990-2020. Atmospheric Environment, 1(45), p. 147-154; http://dx.doi.org/10.1016/j.atmosenv.2010.09.034;

Lemieux P., Stewart E., Realff M., Mulholland J.A. (2004), Emissions study of co-firing waste carpet in a rotary kiln, Journal of Environmental Management, 1(70), p. 2733; http://dx.doi.org/10.1016/j.jenvman.2003.10.002;

Lippiatt B., Ahmad S. (2005), Measuring the lifecycle environmental and economic performance of concrete the BEES approach. Proceedings of the International Workshop on Sustainable Development and Concrete Technology, Beijing;

Madlool N. A., Saidur R., Hossain, Rahim N. A. (2011), A critical review on energy use and savings in the cement industries, Renewable and Sustainable Energy Reviews, 4(15), p. 2042-206; http://dx.doi.org/10.1016/j.rser.2011.01.005;

Middleton N., Yiallouros P., Kleanthous S., Kolokotroni O., Schwartz J., Dockery \& Demokritou P. And Koutrakis P. (2008), A 10-year time-series analysis of respiratory and cardiovascular morbidity in Nicosia, Cyprus: the effect of short term changes in air pollution and dust storms, Environmental Health, 39(7);

O’keefe J. M. K., Henke K. R., Hower J. C., Engle M. K., Stracher G. B.,Stucker J. D., Drew' J. W., Staggs W. D., Murray T.M., Hammond Iii M. L., Adkins K D., Mullins B. J. and Lemley E.W. (2010), $\mathrm{CO}_{2}, \mathrm{CO}$, and $\mathrm{Hg}$ emissions from the Truman Shepherd and Ruth Mullins coal fires, Eastern Kentucky, USA. Science of the Total Environment, 7 (408), p. 1628-1633; http://dx.doi.org/10.1016/j.scitotenv.2009.12.005;

Pak EPA. 2011. Guideleines for Using Tire Derived Fuel (TDF) in Pakistan Cement Industry, Capital Administration and Development Division Pakistan. Pakistan Environmental Protection Agency;

Pak EPA. 2012. National ambient air quality standards. Pakistan Environmental Protection Agency;

Pipilikaki P., Katsioti M., Papageorgiou D., Fragoulis D. and Chaniotakis E. (2005), Use of tyre derived fuel in clinker burning. Cement \& Concrete Composites, 7(27), p. 843-847;

http://dx.doi.org/10.1016/j.cemconcomp.2005.03.009;

Private Power and Infrastructure Board. (2004). Pakistan coal power generation potential;

Sabah A. and Wahab A. (2006), Impact of fugitive dust emissions from cement plants on nearby communities, Ecological Modeling, 3-4 (1 9 5), p. 338-348;

Sharif Q.M., Hussain M., Hilal M. (2005), Chemical characteristics of newly developed coal mines of NWFP. Journal of the chemical society of Pakistan, 27(2), p. 213217 ;

Smith, G. (2003), The world coal trade: a commentary, Department of Economics, University of New England, Australia;

SBP. 2007. The state of Pakistan's economy - first quarterly report. State Bank of Pakistan;

Udeozor O.S. and Nzeako A.N. (2012), An Investigation on the Variation of Vehicular Emissions with Ambient Temperature and Humidity in the Tropics. Global Journal of researches in engineering Automotive engineering, 1(12), 1-6; 
UK coal burning jeopardizes $\mathrm{CO}_{2}$ targets. 2002. Photovoltaics Bulletin, 2(3);

USEPA. 1994. Alternative control techniques document- NOx emissions form cement manufacturing. Emissions Standard Division, California, United States Environment Protection Agency;

Walters, L.J., Johnson, D. E., Macmann, R. S. And Woodward, W. A. Time-Variability of NOx Emissions from Portland Cement Kilns. Environmental Science Technology, 1999, 5 (33), p. 700-704. doi: 10.1021/es980203b;

Ward, T. And Lange, T. The impact of wood smoke on ambient PM2.5 in northern Rocky Mountain valley communities, 2010, Environmental Pollution, 3(158), p. 723-729; http://dx.doi.org/10.1016/j.envpol.2009.10.016;

Yang C., Chang C., Tsai S., Chuang H., Ho C., Wu T. F., Sungc (2003), Preterm delivery among people living around Portland cement plants. Environmental Research, 1(92), p. 64- 68; http://dx.doi.org/10.1016/S00139351(02)00055-5;

Zabaniotou A., Theofilou C. (2008), Green energy at cement kiln in Cyprus-Use of sewage sludge as a conventional fuel substitute. Renewable and Sustainable Energy Reviews, 2(12), p. 531-541; http://dx.doi.org/10.1016/j.rser.2006.07.017.

MSc Fateha Arshed - MPhil Research Scholar (Government College University, Lahore Pakistan), Sustainable Development Study Centre. Main research area: Environmental Monitoring and Sustainable Developments.

Address: $\quad$ Sustainable Development Study Centre, Government College University, Lahore, Pakistan

Tel.: +92-315-4501801

E-mail: ravian355@yahoo.com
PhD Amtul Bari Tabinda - Chairperson Sustainable Development Study Centre (Government College

University, Lahore Pakistan), Sustainable

Development Study Centre.

Main research area: Environmental Chemistry.

Address: Sustainable Development Study Centre, Government College University, Lahore, Pakistan

Tel.: +92-42-9213357-62

E-mail: amtulbaritabinda64@yahoo.com

MSc Syed Ali Raza - Solution environmental analytical laboratory, Kot Lakhpat Lahore. Main research area: Environmental Monitoring, Air, water, soil analysis, environmental consultancy.

Address: Solution environmental analytical laboratory, Kot Lakhpat Lahore, Pakistan

Tel.: $\quad+92-336-4615105$

E-mail: chemstone@yahoo.com

MSc Aleem Butt - Solution environmental analytical laboratory, Kot Lakhpat Lahore.

Main research area: Environmental Monitoring, environmental consultancy.

Address: Solution environmental analytical laboratory, Kot Lakhpat Lahore, Pakistan

Tel.: $\quad+92-321-4260133$

E-mail: aleembutt@hotmail.com

PhD Abdullah Yasar - Government College

University, Lahore Pakistan, Sustainable

Development Study Centre.

Main research area: Waste water management.

Address: Sustainable Development Study Centre Government College University, Lahore, Pakistan

Tel.: +92-42-9213357-62

E-mail: $\quad$ yasar.abdullah@gmail.com 


\title{
Emisijų ị aplinkos orą iš cemento gamyklos, naudojant PAK kaip dalinị anglių pakaitalą, palyginamoji analizė
}

\author{
Fateha Arshed ${ }^{1}$, Amtul B. Tabinda ${ }^{1}$, Syed A. Raza ${ }^{2}$, Aleem Butt ${ }^{2}$, Abdullah \\ Yasar $^{1}$ \\ ${ }^{I}$ Darniosios pletros studiju centras, Lahoro universitetas, Lahoras, Pakistanas \\ ${ }^{2}$ Aplinkos tyrimu laboratorija, Lahoras, Pakistanas
}

(gauta 2014 m. balandžio mèn.; atiduota spaudai 2014 m. birželio mèn.)

\begin{abstract}
Iš padangų atgautas kuras (PAK) turi potencialu pranašumą, nes jis panaudojamas kaip priedas anglies kurui sukamosiose krosnyse cemento gamyklose. Atlikus tyrimą išnagrinèti išmetamų teršalų kriterijai: $\mathrm{CO}_{2}$, $\mathrm{CO}, \mathrm{NO}_{\mathrm{x}}, \mathrm{SO}_{\mathrm{x}}$ ir KD. Jie parinkti tokie norint parinkti tinkamą PAK, galinti pakeisti angli, kiekį, nes iki šiol ivvairios PAK ir anglies proporcijos buvo naudojamos kaip cemento džiovinimo krosnies kuras. $\mathrm{CO}_{2}, \mathrm{CO}, \mathrm{NO}$, $\mathrm{NO}_{2}, \mathrm{SO}_{2}$ ir bendros $\mathrm{KD}(\mathrm{BKD})$ emisijos iš kamino bei $\mathrm{CO}, \mathrm{NO}_{\mathrm{x}}, \mathrm{SO}_{\mathrm{x}}$ ir $\mathrm{KD}_{10}$ koncentracijos aplinkos ore buvo vertinamos taikant JAV AAA rekomenduojamus metodus. Tyrimui buvo naudojamos tokios medžiagu proporcijos: $85 \%$ anglies ir $15 \%$ PAK, $80 \%$ anglies ir $20 \%$ PAK, $75 \%$ anglies ir $25 \%$ PAK ir $70 \%$ anglies ir $30 \%$ PAK. Tyrimo rezultatai parodè, kad didesnis $\mathrm{CO}$ ir BKD emisijų kiekis iš kamino dèl didesnès PAK dalies ir buvo didesnis nei standartas $-80 \%$ anglies ir $20 \%$ PAK. $\mathrm{NO}_{\mathrm{x}}$ išmetimų kiekis sumažejo, naudojant iki $15 \%$ PAK dalies, sudarančios kurą, ir išliko mažesnis nei $\mathrm{NO}_{\mathrm{x}}$ emisijos kiekis, naudojant $100 \%$ anglies kurą, nepaisant to, kad jo koncentracijos didejo, didejjant PAK daugiau nei $15 \%$. Nustatyta, kad aplinkos oro teršalų koncentracijų pokytis nebuvo reikšmingas $(p>0,05)$ nei esant PAK, nei be šio kuro. Tyrimas parodè, kad $15 \%$ PAK yra geriausias tirtos cemento gamyklos pasirinkimas.
\end{abstract}

